TEI

OURNAL OF THE

\section{Journal of the Text Encoding Initiative}

Issue 11 | July 2019 - June 2020

Selected Papers from the 2016 TEI Conference

\title{
Editorial Introduction to Issue 11 of the Journal of the Text Encoding Initiative
}

Claudia Resch, Tanja Wissik and Vanessa Hannesschläger

\section{OpenEdition}

\section{Journals}

Electronic version

URL: http://journals.openedition.org/jtei/3177

DOI: 10.4000/jtei.3177

ISSN: 2162-5603

Publisher

TEl Consortium

\section{Electronic reference}

Claudia Resch, Tanja Wissik and Vanessa Hannesschläger, «Editorial Introduction to Issue 11 of the Journal of the Text Encoding Initiative », Journal of the Text Encoding Initiative [Online], Issue 11 | July 2019 - June 2020, Online since 25 May 2020, connection on 24 September 2020. URL : http:// journals.openedition.org/jtei/3177 ; DOI : https://doi.org/10.4000/jtei.3177

For this publication a Creative Commons Attribution 4.0 International license has been granted by the author(s) who retain full copyright. 


\title{
Editorial Introduction to Issue 11 of the Journal of the Text Encoding Initiative
}

\author{
Claudia Resch, Tanja Wissik, and Vanessa Hannesschläger
}

1 It is with great pleasure that we present another issue of the Journal of the Text Encoding Initiative with papers selected from the sixteenth annual TEI Conference and Members' Meeting, which was hosted by the Austrian Academy of Sciences in Vienna in 2016.

2 This issue illustrates the variety of research that is being done within the TEI community. The call for papers was issued by the Program Committee without limitation to a specific topic. Participants submitted proposals reflecting their wide range of interests, disciplines, and fields of research, opening a huge range of possible approaches.

3 The open call brought almost two hundred participants to Vienna to enjoy a rich conference program comprising thirty-eight papers, seventeen posters, five workshops, and four demos, which are described in the Book of Abstracts. ${ }^{2}$ The conference opened with a keynote address, and continued in seventeen plenary or parallel sessions, a poster session, and four special interest group meetings. As we write these introductory lines-at a time when conference attendance and travel have been limited by a global health crisis-we think back to the conference's social 
program, review the light-hearted photos, and are reminded of how joyful this meeting was and how enduring to the present moment are the connections and encounters that were made by researchers who came from all over the world.

4 TEI 2016 was also a conference of openness. Following the local committee's suggestion, for the first time all abstracts-both digital and print-were published under a Creative Commons Attribution license (CC-BY 4.0). This innovation was adopted at a time when openness was not quite as established within the humanities community as it is today. Such a policy allows both authors and readers (as stated) to redistribute and adapt each other's work as long as the creators are credited, greatly helping to sustain the work of the TEI community and keeping it at the edge of current research trends.

5 The selection of the six papers in this issue are an immediate result of this open sky policy, and reflect the wealth and diversity of topics the TEI community is currently engaged in. As we prepared the volume, we realized the difficulty in finding a planned, coherent order, so we opted for a loose sequence:

6 Claudia Resch, Daniel Schopper, Tanja Wissik, and Daniela Fasching give an overview of the digitization process of a collection of early modern broadsheets from Vienna with particular emphasis on the encoding scheme.

7 Vanessa Hannesschläger discusses the concept of copyright in the context of global laws. She argues that open licenses are vital for ensuring the sustainability of (digital) research data and she showcases the transformation of the abstracts of the TEI2016 conference as an example of how proper licensing can advance research.

8 Helena Bermúdez Sabel describes a method for encoding textual variants that allows the editor to include multiple layers of information in each apparatus tagset.

9 Anja Morgenstern and Agnes Amminger report on the project of editing the early Biographie W. A. Mozart's (1828) by Georg Nikolaus Nissen.

10 Meridith Beck Mink, Michelle Dalmau, Wallace Hooper, William R. Newman, James R. Voelkel, and John A. Walsh describe the Chymistry of Isaac Newton Project, with special attention to the encoding of the citations and references.

11 Nils Geißler and Daniela Schulz describe the building of a collaborative editorial workbench for legal texts with complex structures. 
12 There are many persons to whom the guest editors of the present issue wish to express their gratitude. We should like to take the opportunity to thank all those who were involved in preparing this volume: the members of the editorial board, who engaged in the process and offered essential advice, as well as the authors, who submitted their papers, diligently revised them for publication, and provided a high level of professionalism and commitment.

13 Enjoy the reading.

\section{NOTES}

1 https://tei-c.org/Vault/MembersMeetings/2016/program.html

2 https://tei2016app.acdh.oeaw.ac.at/.

\section{AUTHORS}

\section{CLAUDIA RESCH}

Claudia Resch is a senior researcher and project leader at the Austrian Centre for Digital Humanities (ACDH) of the Austrian Academy of Sciences. Her current research focuses on German literature of the early modern period and the application of literary and linguistic computing in a corpus-based approach to textual issues. Key areas covered are historical linguistics, text stylistics, and annotation problems associated with nonstandard varieties of early modern German. Since 2012 Claudia Resch has been a lecturer in the Department for German Philology of the Ludwig-Maximilians-Universität in Munich, where she teaches digital approaches to textual sources.

\section{TANJA WISSIK}

Tanja Wissik is a senior researcher at the ACDH of the Austrian Academy of Sciences and teaches at the Department of Translation Studies of the University of Graz. She works on numerous national and international research projects in the field of language resources and digital humanities. Her research interests include digital language resources and technologies, especially terminological resources and corpora, workflow research, variational linguistics, and the teaching of DH technologies and methods. 


\section{VANESSA HANNESSCHLÄGER}

Vanessa Hannesschläger is a researcher at the Austrian Centre for Digital Humanities of the Austrian Academy of Sciences (ACDH-OEAW), where she is responsible for legal issues. She is involved in several projects in which she works on data modeling, on digital editing, and in the outreach department. In addition, she is completing her PhD with the German department of the University of Vienna. Her research interests include legal frameworks of digital research, biography theory, archive theory, modern Austrian literature, and the contemporary developments of gender issues in society. For more information, please visit https:// vanessahannesschlaeger.wordpress.com/. 